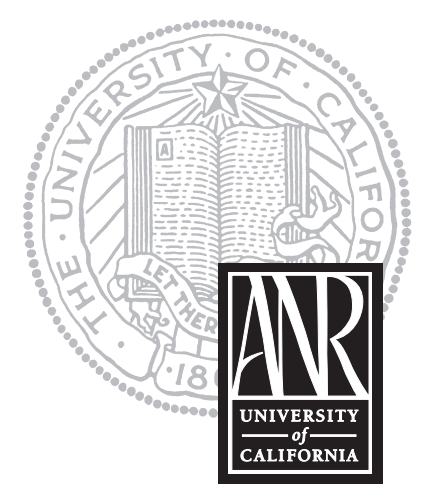

\section{UNIVERSITY OF} CALIFORNIA

Division of Agriculture and Natural Resources

http://anrcatalog.ucdavis.edu

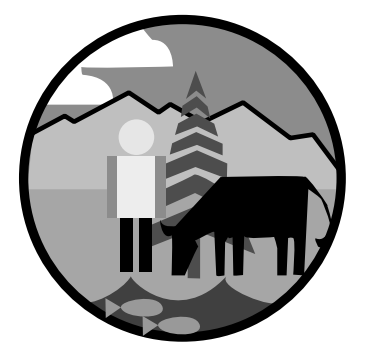

California Rangelands Research and Information Center

http://agronomy.ucdavis.edu/ calrng/range1.htm

\title{
Using Stage of Maturity to Predict the Quality of Annual Range Forage
}

MELVIN R. GEORGE, Cooperative Extension Range Specialist, UC Davis; and MARYA E. BELL, Graduate Research Associate, Agronomy and Range Science, UC Davis

M

ost ranchers and range management professionals are aware that forage plants decline in nutritional value as they advance in maturity. The relationship of nutritional value and stage of maturity has been reviewed for range plants by Kilcher (1981) and for forage crops by Fick et al. (1994). During the first Range Nutrition Short Course conducted by University of California Cooperative Extension in 1993 it became apparent that many ranchers understood this relationship, but most were unable to estimate crude protein (CP) accurately from stage of maturity. Most range management professionals are also uncertain of approximate $\mathrm{CP}$ levels at different stages of maturity. The information in this publication can be used by range managers to estimate $\mathrm{CP}$ for some common California foothill range plants, if they know the stage of maturity.

We believe that range managers would find an understanding of this relationship to be useful in making supplemental feeding and other range animal nutrition decisions, especially if they were to use it in combination with other monitoring techniques such as body condition scoring and fecal analysis (Lyons and Stuth 1992). Using data from forage samples collected and analyzed in the 1930s, this paper demonstrates that stage of maturity is a useful indicator or predictor of $\mathrm{CP}$ but is not a strong predictor of crude fiber (CF), calcium, or phosphorus.

Table 1. Common and scientific names for range plants circa 1930 and 2000

\begin{tabular}{lll}
\hline Common name & Scientific name (1930) & Scientific name (2000) \\
\hline annual fescue & Festuca megalura & Vulpia myuros \\
ripgut brome & Bromus rigidus & Bromus diandrus \\
soft chess brome & Bromus mollis & Bromus hordeaceus \\
Australian chess & Bromus arenarius & Bromus arenarius \\
wild oats & Avena barbata & Avena barbata \\
red brome & Bromus rubens & Bromus madritensis spp. rubens \\
whitestem filaree & Erodium moschatum & Erodium moschatum \\
redstem filaree & Erodium cicutarium & Erodium cicutarium \\
broadleaf filaree & Erodium botrys & Erodium botrys \\
bur clover & Medicago polymorpha & Medicago polymorpha
\end{tabular}

\section{OLD DATA, MODERN ANALYSIS}

California range and animal scientists conducted exhaustive studies of seasonal range forage quality in the 1930s, reporting sampling date, stage of maturity, and levels of several nutrients. Using data from these reports, we determined the influence of stage of maturity on $\mathrm{CP}, \mathrm{CF}$, calcium, and phosphorus using linear regression.

Hart et al. (1932) published a report on seasonal forage quality in California's annualdominated Mediterranean rangelands. In 1930 and 1931, they sampled soft chess brome, wild oats, whitestem filaree, redstem filaree, broadleaf filaree, and bur clover (Table 1) on 17 foothill ranches from Tehama County to Kern County (Figure 1). Beginning with early vegetative stages, a sample of each species was collected at monthly intervals until rains had ceased and the forage had matured and dried. During the remainder of the year, samples of the dry forage were collected at longer intervals. Crude protein, crude fiber, and calcium were deter- 
Figure 1. Forage sampling locations: SE of Oakdale (grassland), E of Merced (grassland), E of Madera (grassland-rolling plains), NE of Madera, E of Fresno (grassland-rolling plains), E of Madera (oak woodland-granitic soils), Coalinga (grassland-Kettleman loam and clay loam), SE of Porterville (grassland), SE of Porterville (oak woodland-granitic soils), SW of Red Bluff (grassland-sedimentary soils), W of Red Bluff, E of Red Bluff (lava foothills), W of Red Bluff (oak woodland), W of Marysville (oak woodland-Sutter Buttes), SE of Marysville (oak woodland-reddish gravelly soil), S of Folsom (grassland), $\mathrm{N}$ of lone (cleared oak-woodland/chaparral, $\mathrm{N}$ of lone (oak woodland), NE of Madera (oak-woodland-San Joaquin Experimental Range).

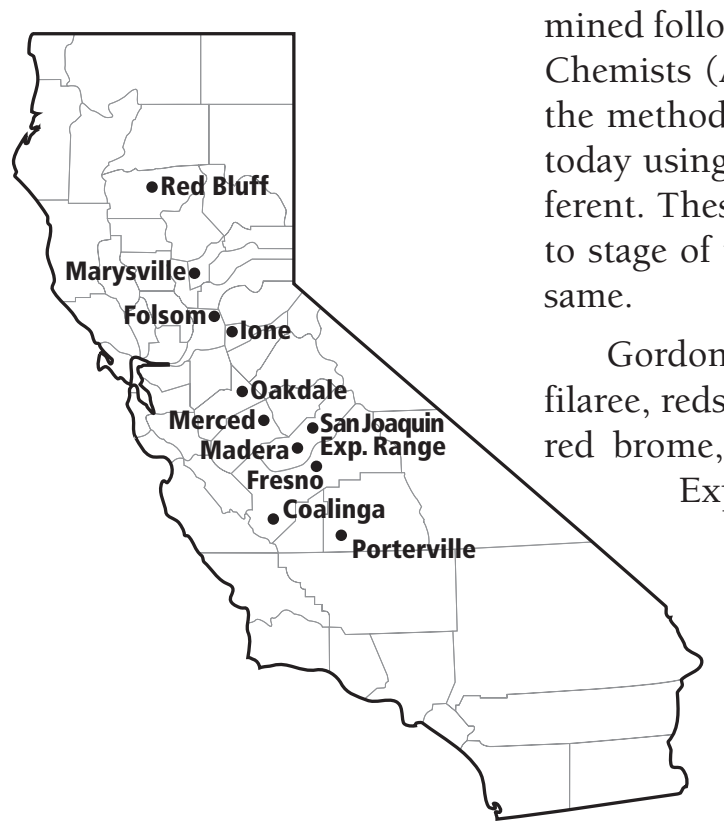

mined following official methods outlined by the Association of Official Agricultural Chemists (A.O.A.C. 1925). Phosphorus was determined colorimetrically following the methods of Fiske and Subbarow (1925). If these forage samples were analyzed today using current methods, the results for $\mathrm{CP}, \mathrm{CF}, \mathrm{Ca}$, and $\mathrm{P}$ values would be different. These differences would be small, however, compared to the differences due to stage of maturity, and the reported seasonal trends ultimately would remain the

Gordon and Sampson (1939) reported the nutrient composition of broadleaf filaree, redstem filaree, whitestem filaree, wild oats, soft chess brome, ripgut brome, red brome, and annual fescue (Table 1) sampled seasonally at the San Joaquin Experimental Range in Madera County from 1934 to 1937. The researchers followed the same A.O.A.C. methods for determining CP and calcium. Crude fiber was determined using the methods of Sharrer and Kurschner (1931-32), and phosphorus was determined by the methods of Kuttner and Cohen (1927).

We followed the standard stages of maturity (National Research Council 1982) in renaming the stages used in the 1932 and 1939 reports. Numerical values from 1 to 12 were assigned to these standard stages of maturity (Table 2). Crude protein, crude fiber, calcium, and phosphorus levels were regressed on these stages of maturity. To increase the sample size at each stage of maturity, we pooled data from six annual grasses for analysis. Similarly, data for three species of filaree were pooled for analysis.

\section{RESULTS AND DISCUSSION}

The regression of $\mathrm{CP}$ on stage of maturity explained most of the variation in $\mathrm{CP}$ for six annual grasses $\left(r^{2}=0.79\right)$, filaree $\left(r^{2}=0.76\right)$, and bur clover $\left(r^{2}=0.71\right)$ (Figure 2). The results of our study indicate that for each advance in one stage of maturity, CP declines $1.44,2.14$, and 1.15 percent respectively for annual grasses, filaree, and bur clover. Filaree and bur clover started the growing season with higher $\mathrm{CP}$ levels than the annual grasses. As the growing season progressed, CP for filaree declined more rapidly than for bur clover or the annual grasses. Like many forage legumes, bur clover maintained higher $\mathrm{CP}$ as it matured than did the grasses or filaree.

Crude fiber increased with stage of maturity. This relationship was not so strong as for CP. Nonetheless, stage of maturity partially explained the variation in CF for six annual grasses $\left(r^{2}=0.37\right)$, filaree $\left(r^{2}=0.64\right)$, and bur clover $\left(r^{2}=0.58\right)$ (Figure 3$)$.

Calcium and phosphorus declined with stage of maturity. Stage of maturity explained most of the
Table 2. Numerical stage of maturity used to predict crude protein, crude fiber, phosphorus, and calcium content of annual grasses, filaree, and bur clover

\begin{tabular}{cc}
\hline $\begin{array}{c}\text { Stage } \\
\text { number }\end{array}$ & $\begin{array}{c}\text { Stage } \\
\text { description }\end{array}$ \\
\hline 1 & germinated \\
2 & early vegetative \\
3 & late vegetative \\
4 & early bloom \\
5 & mid bloom \\
6 & full bloom \\
7 & late bloom \\
8 & milk stage \\
9 & dough stage \\
10 & mature \\
11 & dry \\
12 & dry leached \\
\hline
\end{tabular}



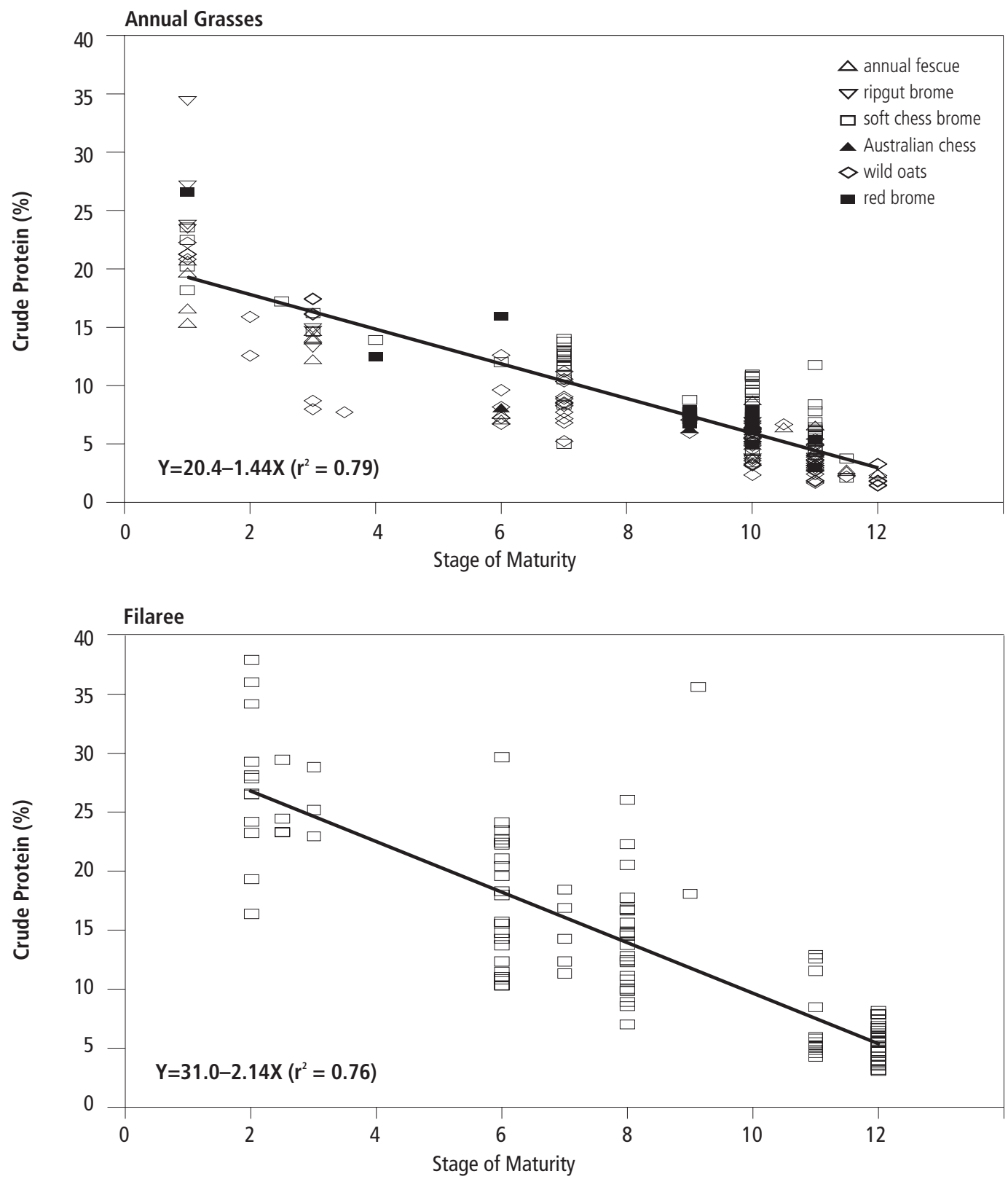

Figure 2. Stage of maturity and crude protein for annual grasses, filaree, and bur clover.

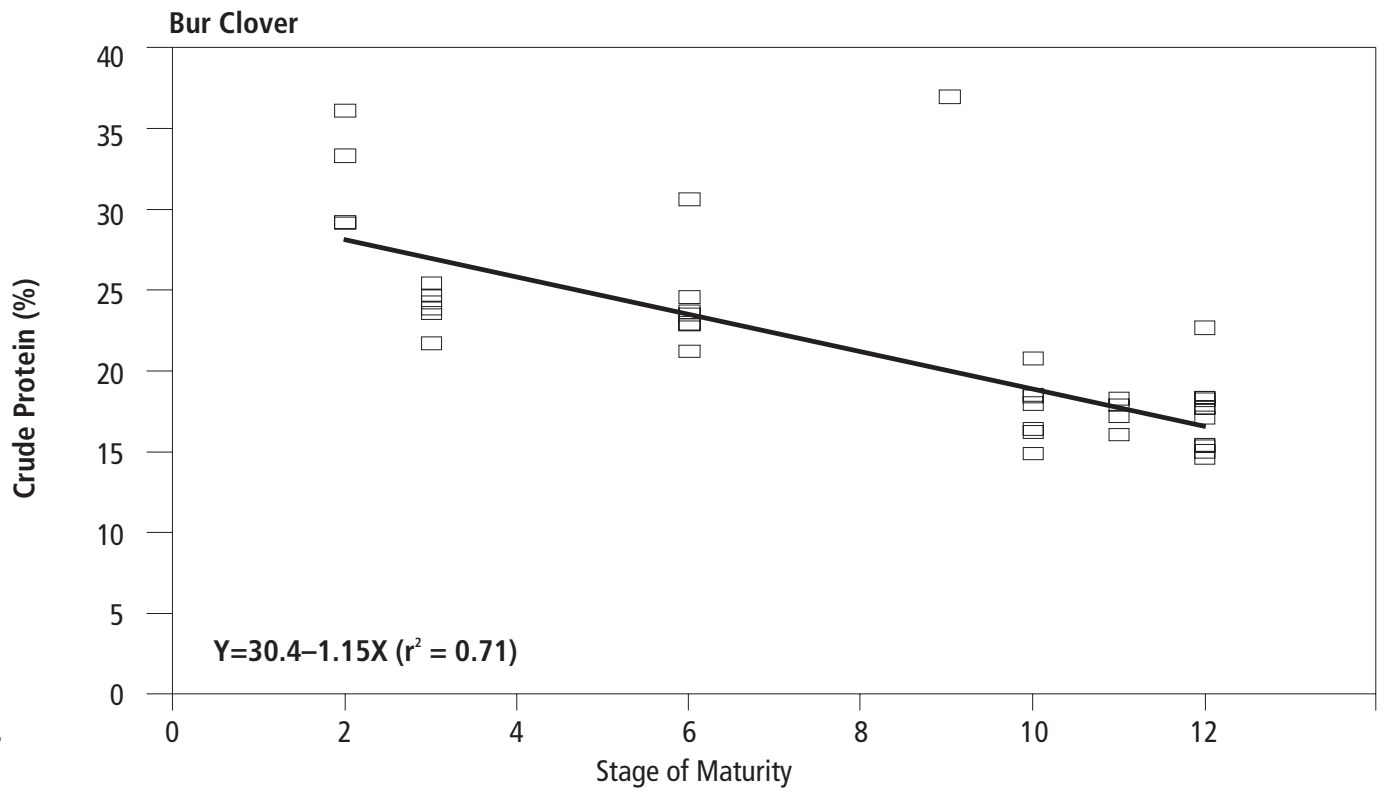



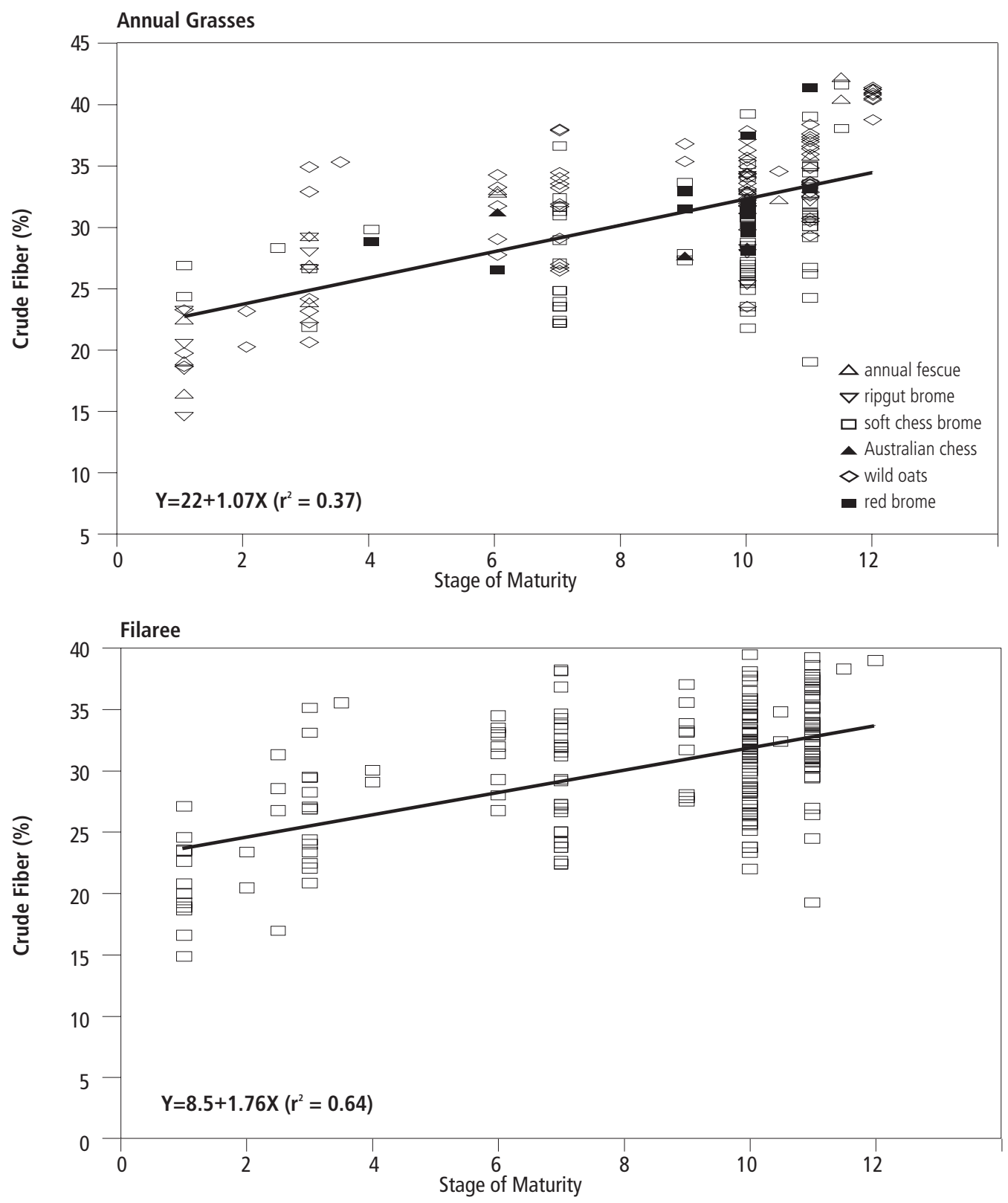

Figure 3. Stage of maturity and crude fiber for annual grasses, filaree, and bur clover.

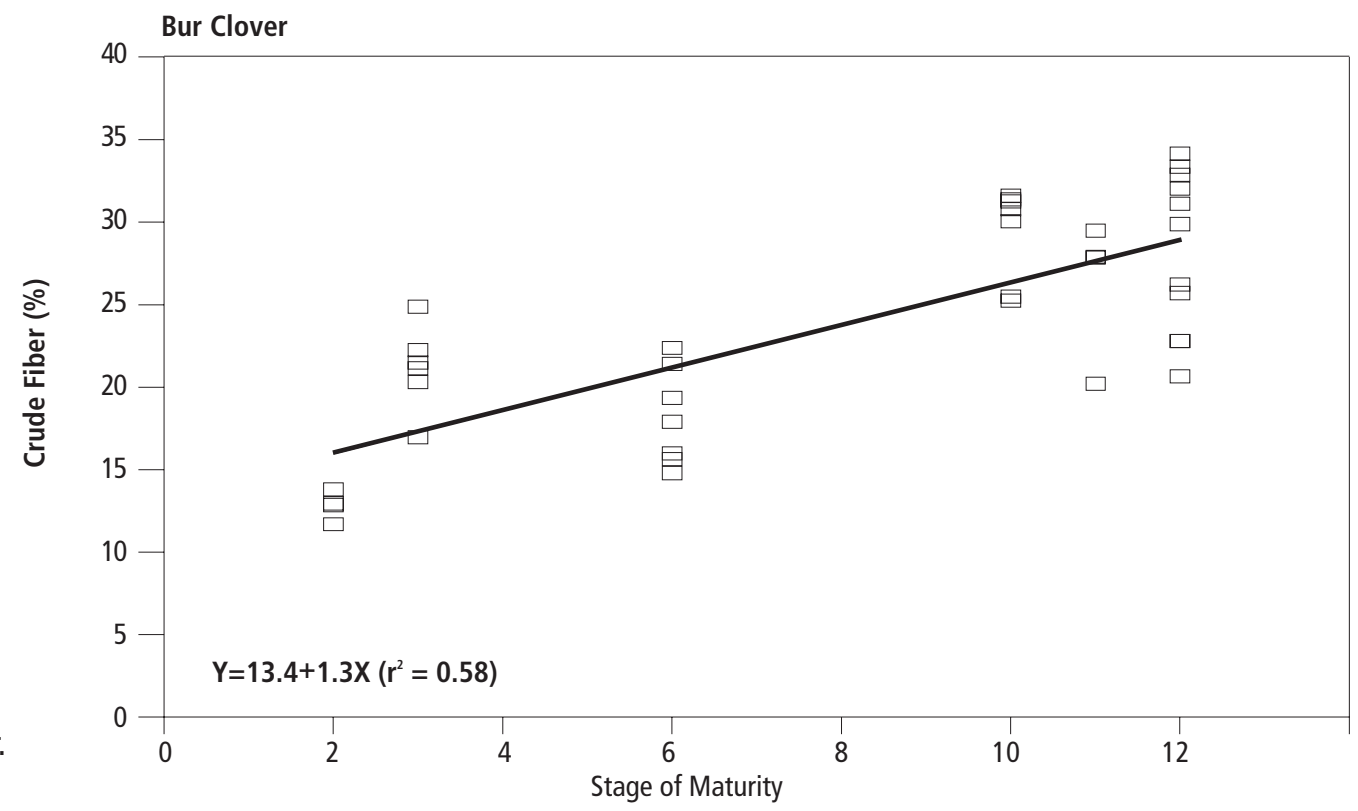


variation in calcium $\left(r^{2}=0.56\right)$ and phosphorus $\left(r^{2}=0.64\right)$ for six annual grasses (Figure 4).

While stage of maturity provided sufficient explanation for variations in CP for annual grasses, filaree, and bur clover, the stage of maturity was not as strong a predictor of CF, calcium, or phosphorus. Other factors such as temperature, soil moisture, soil fertility, and plant species may be important determinants of CF, phosphorus, and calcium, together with stage of maturity.

Angell et al. (1990) regressed CP on stage of maturity (phenology) for crested wheatgrass (Agropyron desertorum (Fisch. ex Link) Schult). The regression equation for 5 years of pooled samples was $\mathrm{Y}=13.88-1.167 \mathrm{X}\left(\mathrm{r}^{2}=0.85\right)$. Crested wheatgrass $\mathrm{CP}$ was lower in early vegetative stages and declined at a slower rate than did the annual grasses reported in this study. Like the annual grasses, crested wheatgrass CP declined to less than 5 percent. The crested wheatgrass sampling ended a few weeks after flowering each year, whereas the annual grasses and forbs were sampled throughout the year and included dry samples that had been leached by fall and winter rains.

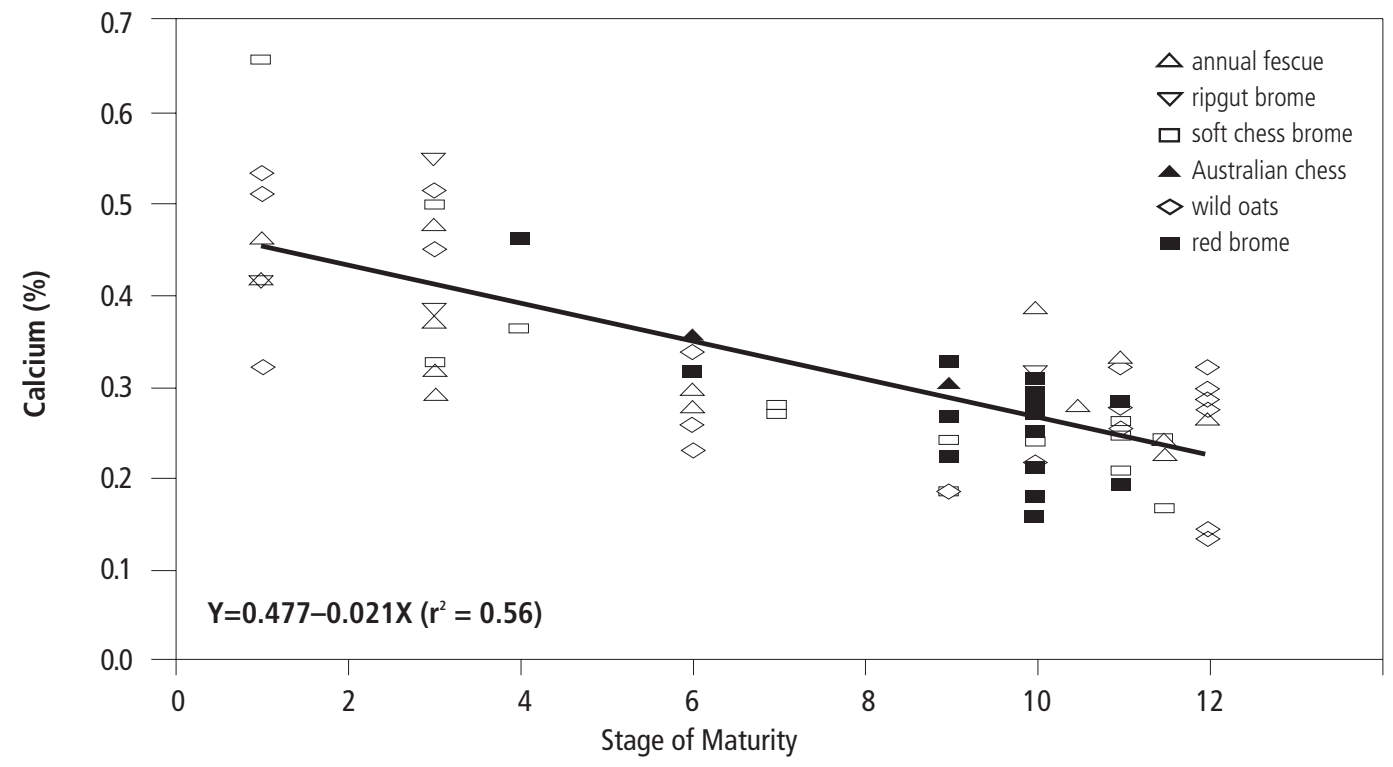

Figure 4. Stage of maturity, calcium, and phosphorus for annual grasses.

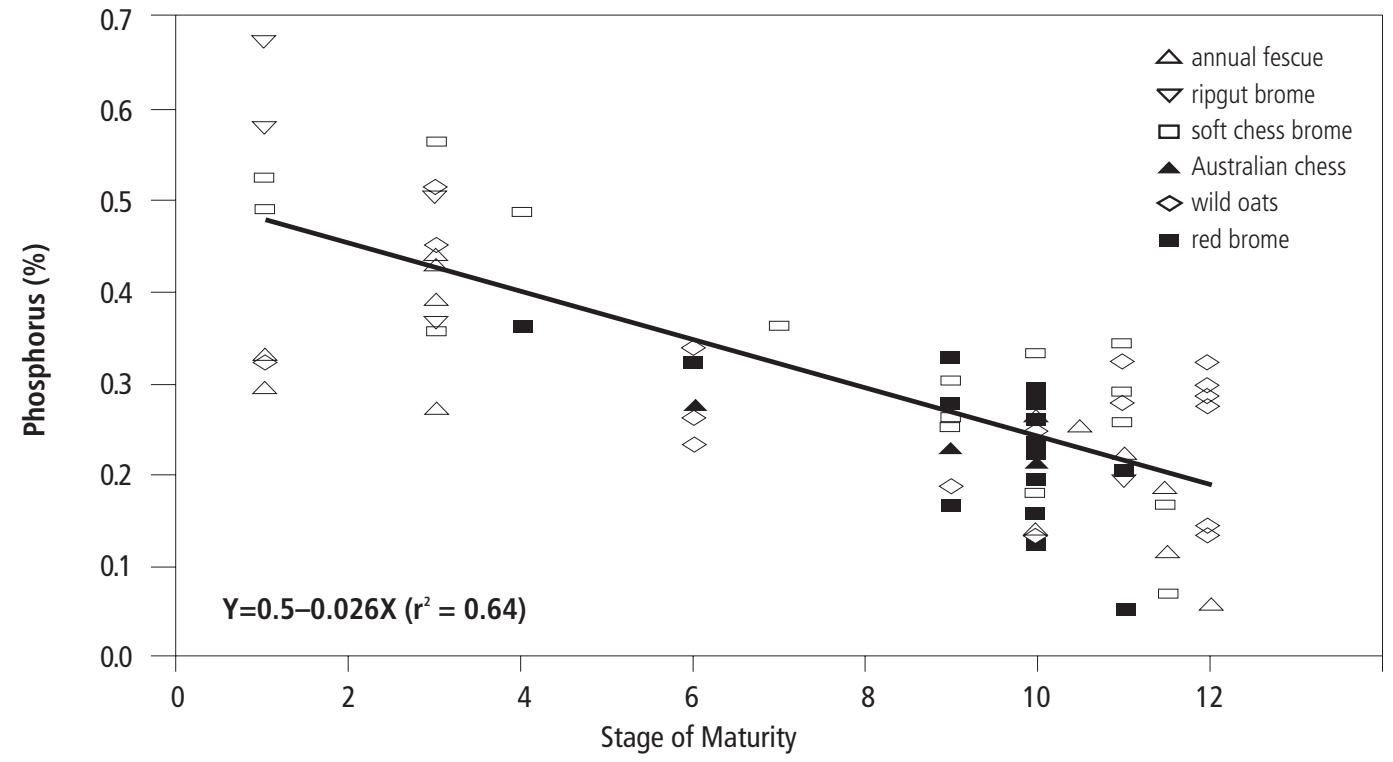


More recent studies have also reported seasonal forage quality for annual rangelands (see UC ANR Publication 8022, Annual Rangeland Forage Quality). Morris and Delmas (1980) reported seasonal variations in phosphorus, copper, calcium, potassium, and sodium in range forage, and Morris (1984) reported organic matter digestibility and CP in forage samples from esophageal fistulated steers. Raguse et al. (1989) determined that rose clover (Trifolium hirtum L.) phenology could be used as a cue to an impending decline in average daily gain among steers grazing on annual rangeland seeded with rose clover and subterranean clover (T. subterraneum L.). He found that when half of the rose clover plants were green (with at least half of the heads flowering) and half of the plants were beginning to dry (with flower color disappearing on half of the heads) average daily gain would begin to decrease. If the majority of rose clover plants were completely dry, average daily gain was already declining.

The results of our study show that the plants' stage of maturity can be used to estimate the crude protein of annual grasses, filaree, and bur clover in California's annual rangelands. When observing stage of maturity, you should observe several shoots and average them using the values in Table 2 (Fick et al. 1994). Use of this information together with other monitoring tools such as body condition scoring and emerging techniques such as NIR, fecal analysis, and decision support systems will improve the quality of range livestock managers' supplemental feeding decisions and will reduce feeding costs of range cow operations (Lyons and Stuth 1992).

\section{LITERATURE CITED}

A.O.A.C. 1925. Methods of analysis. Washington, DC: Assoc. of Official Agric. Chemists. 535 pp.

Angell, Raymond F., Richard F. Miller, and Marshall R. Haferkamp. 1990. Variability of crude protein in crested wheatgrass at defined stages of phenology. J. Range Manage. 43:186-89.

Fick, Gary W., Paul W. Wilkens, and Jerome H. Cherney. 1994. Modeling forage quality changes in the growing crop. pp. 757-95. In Fahey, George C. (ed.). 1994. Forage quality, evaluation and utilization. Madison, WI: Amer. Soc. of Agronomy.

Fiske, C. H., and Y. Subbarow. 1925. The colorimetric determination of phosphorus. J. Biol. Chem. 66:375-400.

Gordon, Aaron, and Arthur W. Sampson. 1939. Composition of common California foothill plants as a factor in range management. Bulletin 627. Berkeley: Univ. of Calif. Agric. Exp. Sta. 95 pp.

Hart, G. H., H. R. Guilbert, and H. Goss. 1932. Seasonal changes in the chemical composition of range forage and their relation to nutrition of animals. Bulletin 543. Berkeley: Univ. of Calif. Agric. Exp. Sta. 62 pp.

Kilcher, M. R. 1981. Plant development, stage of maturity and nutrient composition. J. Range Manage. 34:363-64.

Kuttner, T., and H. R. Cohen. 1927. Micro colorimetric studies. J. Biol. Chem. 75:517-31.

Lyons, Robert K., and Jerry W. Stuth. 1992. Fecal NIRS equations for predicting diet quality of free-ranging cattle. J. Range Manage. 45:238-44.

Morris, J. G. 1984. Energy balance of grazing beef cows. Report of the Beef and Range Field Day, Univ. of Calif. Sierra Foothill Range Field Station, Browns Valley, CA. pp. 4-7. 
Morris, J. G., and R. E. Delmas. 1980. Seasonal variation in the nutritive nature of Californian range forage for cattle. Report for Beef Cattle Day, Univ. of Calif. Sierra Foothill Range Field Station, Browns Valley, CA. pp. 16-20.

National Research Council. 1982. United States-Canadian tables of feed composition. Washington, DC: National Academy Press. p. 144.

Raguse, Charles A., James G. Morris, and Virginia N. Landry. 1989. Correlation of steer average daily gain with diet quality and forage phenology in an improved annual grassland. J. Range Manage. 42(5):415-20

Sharrer, K., and K. Kurschner. 1931-32. Ein neues, rasch Durchfuhrbares verfahren zur Bestimmung der Rohfaser in Futtermitteln. Die Tierernahrung. 3:302-10.

\section{FOR MORE INFORMATION}

You'll find detailed information on many aspects of rangeland and livestock management in these titles and in other publications, slide sets, and videos from UC ANR:

A Planner's Guide for Oak Woodlands, publication 3369

Monitoring California's Annual Rangeland Vegetation, publication 21486

Residual Dry Matter Guidelines for California Annual Rangelands, slide set 88/102

To order these products, visit our online catalog at http://anrcatalog.ucdavis.edu. You can also place orders by mail, phone, or fax, or request a printed catalog of publications, slide sets, and videos from

University of California

Division of Agriculture and Natural Resources

Communication Services

6701 San Pablo Avenue, 2nd Floor

Oakland, California 94608-1239

Telephone: 1-800-994-8849 or (510) 642-2431, FAX: (510) 643-5470

e-mail inquiries: danrcs@ucdavis.edu

An electronic version of this publication is available on the DANR Communication Services website at http://anrcatalog.ucdavis.edu.

\section{Publication 8019}

(C) 2001 by the Regents of the University of California, Division of Agriculture and Natural Resources. All rights reserved.

The University of California prohibits discrimination against or harassment of any person employed by or seeking employment with the University on the basis of race, color, national origin, religion, sex, physical or mental disability, medical condition (cancer-related or genetic characteristics), ancestry, marital status, age, sexual orientation, citizenship, or status as a covered veteran (special disabled veteran, Vietnam-era veteran or any other veteran who served on active duty during a war or in a campaign or expedition for which a campaign badge has been authorized).

University Policy is intended to be consistent with the provisions of applicable State and Federal laws.

Inquiries regarding the University's nondiscrimination policies may be directed to the Affirmative Action/Staff Personnel Services Director, University of California, Agriculture and Natural Resources, 1111 Franklin, 6th Floor, Oakland, CA 94607-5200 (510) 987-0096.

pr-4/01-WJC/CR

This publication has been anonymously peer reviewed for technical accuracy by University of California scientists and other qualified professionals. This review process was managed by the ANR Associate Editor for Natural Resources. 